\title{
Pull-apart origin of the Satpura Gondwana basin, central India
}

\author{
Chandan Chakraborty* and Sanjoy Kumar Ghosh \\ Geological Studies Unit, Indian Statistical Institute, 203, B.T. Road, Kolkata 700 108, India. \\ *e-mail: chandan@isical.ac.in
}

The Gondwana basins of peninsular India are traditionally considered as extensional-rift basins due to the overwhelming evidence of fault-controlled synsedimentary subsidence. These basins indeed originated under a bulk extensional tectonic regime, due to failure of the attenuated crust along pre-existing zones of weakness inherited from Precambrian structural fabrics. However, disposition of the basins and their structural architecture indicate that the kinematics of all the basins cannot be extensional. To maintain kinematic compatibility with other basins as well as the bulk lateral extension, some basins ought to be of strike-slip origin. The disposition, shape and structural architecture of the Satpura basin, central India suggest that the basin could be a pull-apart basin that developed above a releasing jog of a left-stepping strike-slip fault system defined by the Son-Narmada south fault and Tapti north fault in consequence to sinistral displacement along WSW-ENE. Development of a sedimentary basin under the above-mentioned kinematic condition was simulated in model experiments with sandpack. The shape, relative size, stratigraphic and structural architecture of the experimental basin tally with that of the Satpura basin. The experimental results also provide insights into the tectono-sedimentary evolution of the Satpura basin in particular and pull-apart basins in general.

\section{Introduction}

The Satpura basin is the westernmost Gondwana basin exposed in the peninsular region (figure 1; cf. Robinson 1967). It is unique among all the Indian Gondwana basins by having the longest range of stratigraphic record spanning from Permian to Cretaceous (Crookshank 1936; table 1). Recently, it has been demonstrated that the Gondwana basins of peninsular India developed under a bulk extensional regime but the kinematics of the individual basins were variable ranging between extensional and pull-apart (Chakraborty et al 2003a). The study revealed that the Satpura basin is of pull-apart origin. The purpose of this paper is to understand the progressive tectonosedimentary evolution of this basin with the help of analog model experiments and corroborative field data.

\section{Tectonic framework of the Gondwana basins of peninsular India}

The major significance of the Indian Gondwana strata is that they mark initiation of sedimentation in peninsular India in the Permo-Carboniferous time after a long depositional hiatus beginning at the end of Proterozoic. The successions are similar to the time-equivalent strata of South America, South Africa, Australia and Antarctica - the constituents of the southern hemispheric part (Gondwanaland) of the Paleozoic supercontinent Pangea. All these successions, in general, start with basal diamictite and glacial outwash deposits, followed successively by coal-bearing siliciclastics with Glossopteris and Triassic red beds with calcretes, and contain similar fossil assemblages (Hobday 1987).

The Gondwana basin-fills of peninsular India are unmetamorphosed and the original basin

Keywords. Basin tectonics; strike-slip basin; transcurrent zone; step-over; subsidence. 
A
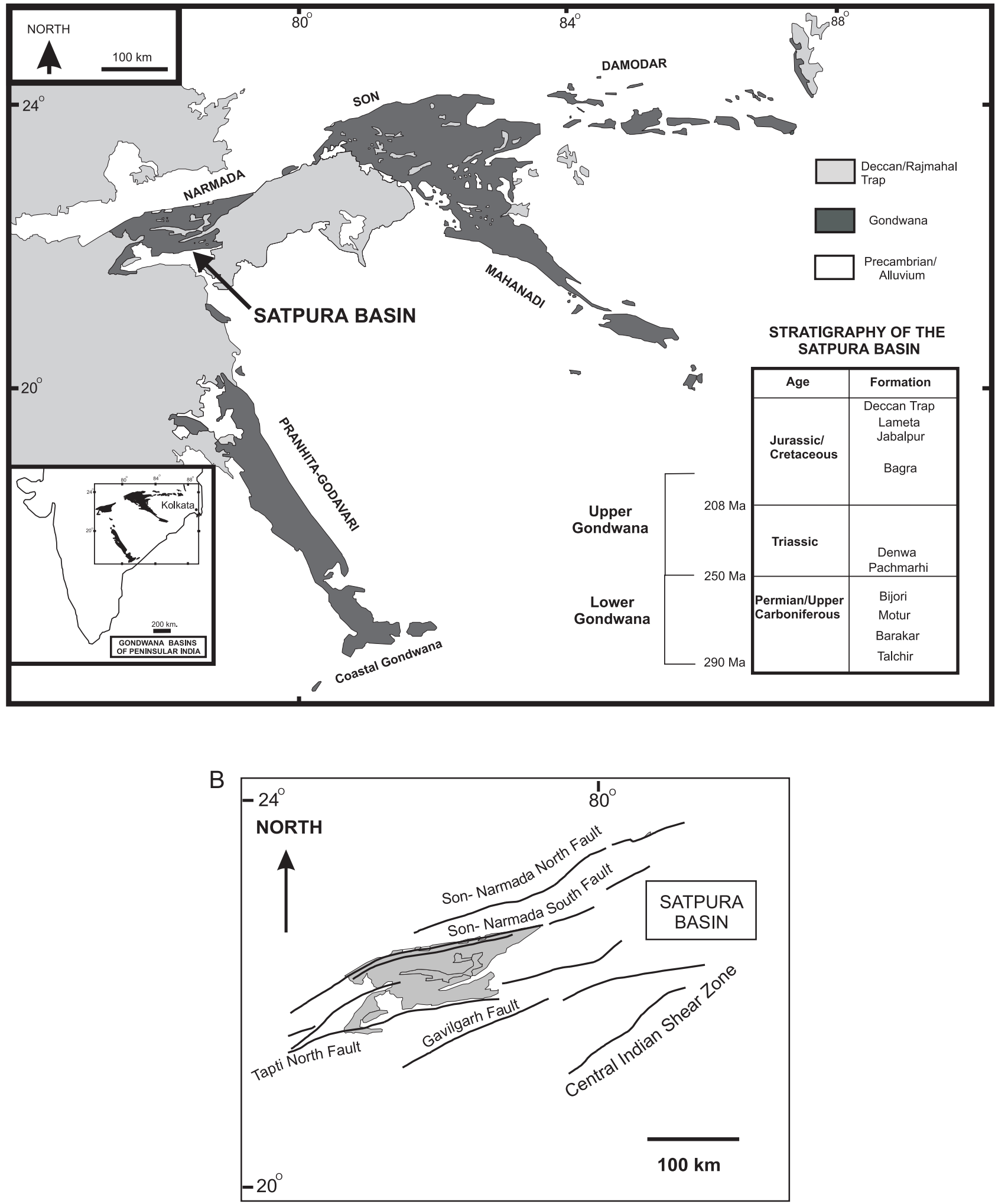

Figure 1. (A) Outcrops of the Gondwana basins in peninsular India. Note their occurrence along three distinct belts following the present day valleys of Narmada-Son-Damodar, Pranhita-Godavari and Mahanadi rivers. The present study is confined to the Satpura basin. Stratigraphy of the Satpura basin-fill is also shown. Inset shows the Indian peninsula. (B) Major boundary faults of the Satpura basin (based on Narula et al 2000). Shaded area represents the outcrop of the basin. 
architecture is more or less preserved. The strata crop out along three distinct linear belts are defined by the present day river valleys of (1) NarmadaSon-Damodar (NSD), (2) Pranhita-Godavari (PG), and (3) Mahanadi (M) (figure 1). The basin-belts are flanked by regionally persistent dislocation zones of antiquity (Narula et al 2000). The basin-fills in some cases are asymmetric with an overall increase in thickness towards one of the boundary faults indicating that the basin bounding faults were active during sedimentation inducing subsidence and creating space for stratigraphic preservation of sediments. The basin-fill strata are also affected by intrabasinal gravity faults reflecting synsedimentary downward displacements that generated accommodation space for sediment accumulation throughout the history of basin evolution (Basu and Shrivastava 1980; Raja Rao 1982, 1983, 1987). The Bouguer gravity anomaly contours, as well as drill hole data again indicate significant thickness of subsurface Gondwana strata in all the basins implying synsedimentary tectonic subsidence (Veevers and Tewari 1995; Mishra et al 1999). The northern boundaries of many of the Gondwana basins occurring along the NSD valley are marked by the Son-Narmada lineament (figure 1B). This lineament is considered to have formed in the Precambrian, re-activated many times subsequently and is still a zone of seismicity (Naqvi et al 1974; Crawford 1978; Das and Patel 1984; Kaila 1986). The Son-Narmada lineament has been demonstrated as a trans-continental wrench system that in the Gondwanaland assembly extended from Madagaskar up to Australia through the Indian subcontinent (Crawford 1978; Harris and Beeson 1993). The development of the Gondwana basins was related to a regional ENE-WSW bulk extension of the rigid basement containing pre-existing weak zones (Chakraborty et al 2003a). The ENEWSW bulk extension of the crust gave rise to the Pranhita-Godavari and Mahanadi basins, and the bulk extensional regime was terminated in the north by strike-slip zones along the ENE-WSW trending Son-Narmada lineament to maintain displacement compatibility with the tectonics of the Pranhita-Godavari and Mahanadi basins as well as the bulk ENE-WSW lateral extension (cf. Biswas 1999, 2003; Chakraborty et al 2003a).

\section{Structural framework of the Satpura basin}

The Satpura basin is the westernmost of the series of basins occurring along the Narmada-SonDamodar valley, which also marks the junction of the Pranhita-Godavari valley and Narmada-
Son-Damodar valley (figure 1). The basin is filled with around $5 \mathrm{~km}$ thick siliciclastic succession. The sedimentological attributes of the succession are summarised in table 1.

The Satpura basin $(\sim 200 \mathrm{~km}$ long, $\sim 60 \mathrm{~km}$ wide) is rhomb-shaped, relatively long in the ENEWSW direction and its longer sides are marked by the ENE-WSW trending Son-Narmada south fault and Tapti north fault in the north and south respectively (figure $2 \mathrm{~A}$ ). These faults are subvertical near the surface and show evidence of strike-slip movements (Crawford 1978; Das and Patel 1984; Biswas 1999, 2003). The western margin of the basin is also marked by a fault trending NE-SW and linking the strike-slip margins (figure 2A).

The regional strike of the basin-fill strata is $\mathrm{NE}-\mathrm{SW}$, and the regional dip $\left(\sim 5^{\circ}\right)$ is northerly. There are numerous faults affecting the basinfill strata (figure 2C). These faults are intrabasinal in the sense that they are confined within the basin and do not transgress the basin bounding faults mentioned earlier. That many of these faults are synsedimentary is reflected in the thickening of hangingwall strata towards the fault plane, as well as from the fact that the frequency of intrabasinal faults decreases towards younger formations (cf. Raja Rao 1983). The Talchir and Barakar Formations are affected by faults more than the other formations. The intrabasinal faults are normal in nature. The dominant set trends along ENE-WSW, making positive acute angles of around $10^{\circ}-20^{\circ}$ with the northern and southern boundary faults (figure 2C). There are also faults making negative acute angles $\left(10^{\circ}-20^{\circ}\right)$ with the boundary faults. A subordinate set of faults trends along NW-SE, making high angles $\left(\sim 70^{\circ}\right)$ with the basin bounding faults (figure $2 \mathrm{C}$ ). Some of the faults branch out and rejoin resembling a braided pattern.

Subsurface mapping of the coal seams of the Barakar Formation also revealed the presence of synsedimentary normal faults (figure 3A). These faults show a similar pattern of arrangement as discussed above. There are two sets of faults: (1) a set trending parallel to the northern and southern basin margin faults, and (2) a set of $\mathrm{NE}-\mathrm{SW}$ trending cross faults linking the first set of faults (figure 3A). The cross-sectional profile reveals asymmetric half-graben configuration with thickening of hangingwall strata towards northerly occurring and southerly dipping faults indicating synsedimentary, fault-controlled subsidence (figure 3B).

The rhombohedral shape of the Satpura basin bounded by fault lineaments merging with leftstepping strike-slip zones (figure 2A), and the presence of intrabasinal cross-faults making positive acute angles with the boundary faults (figure $2 \mathrm{C}$ ) 
Table 1. Sedimentary attributes and thicknesses of different stratigraphic units of the Satpura basin.

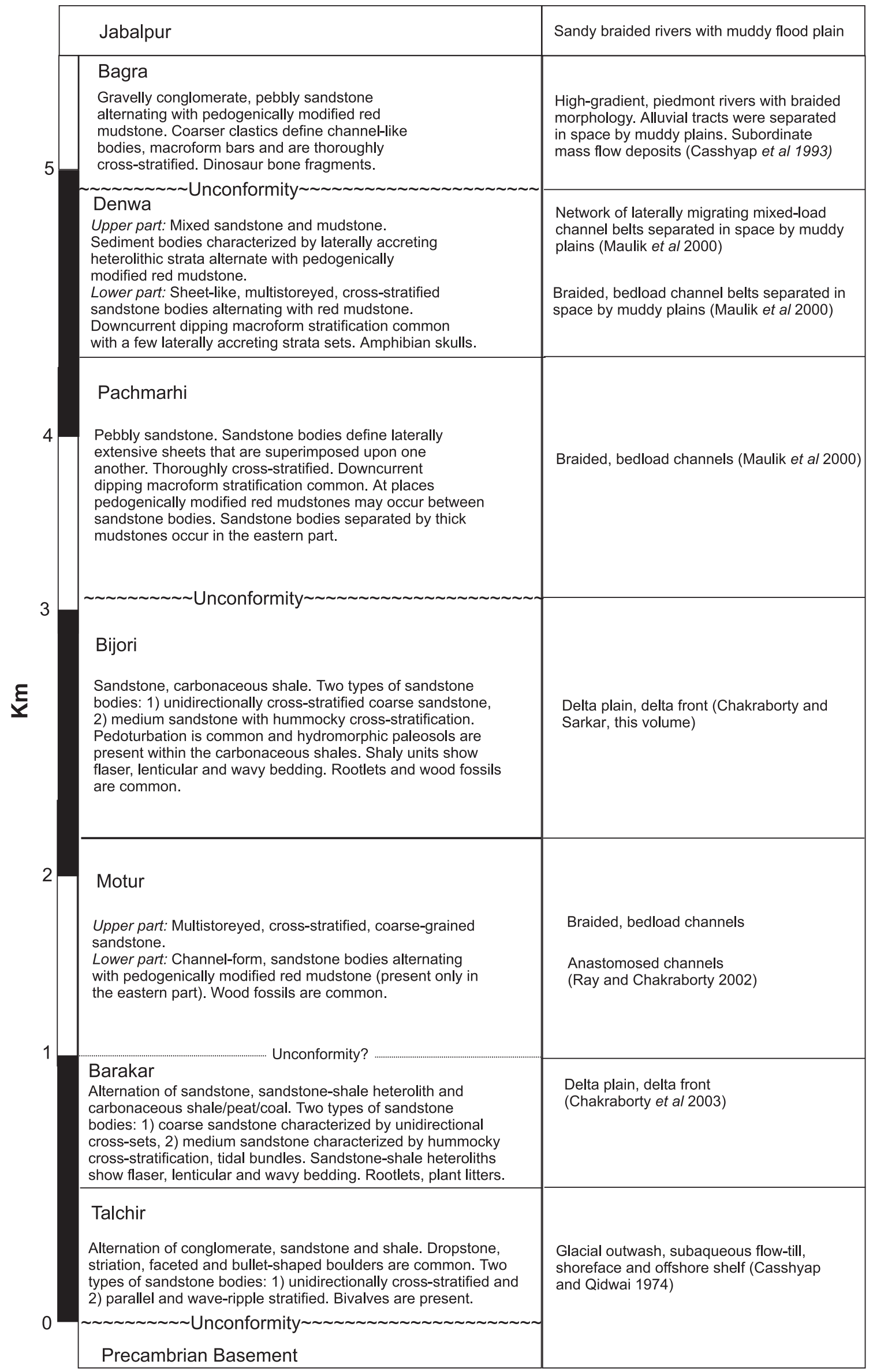



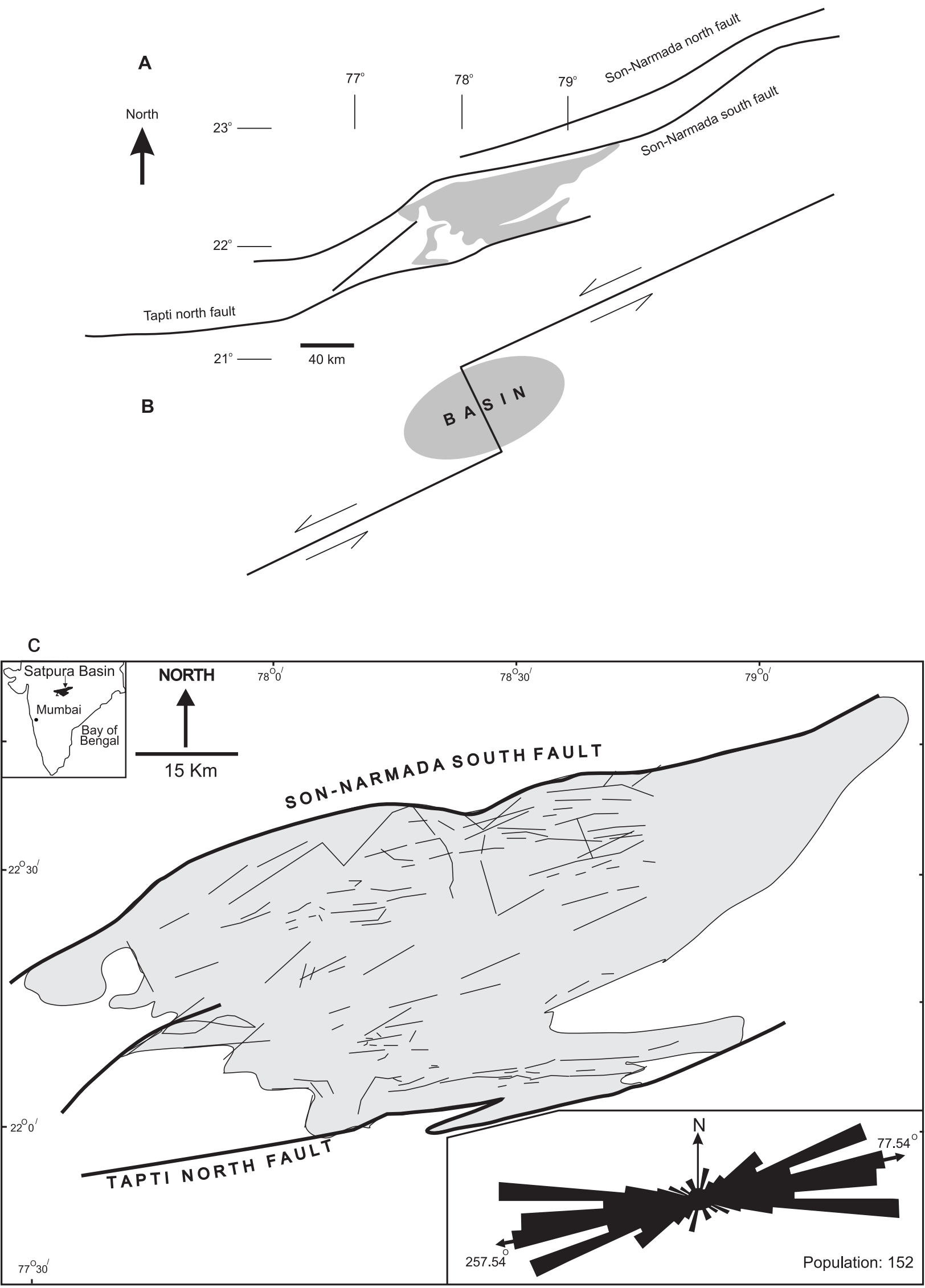

Figure 2. (A) and (B) Fault kinematics related to the formation of the Satpura basin as inferred from the fault disposition shown in (A). Note that the basin initiates above the stepover of a left-stepping strike-slip zone as a result of sinistral fault motion. (C) Disposition of faults confined within the Satpura basin. The rose diagram depicts the orientation of the faults. See text for details. Based on Raja Rao (1983), Peters and Singh (2001), Chakraborty et al (2003a) and new data from this study. 
A
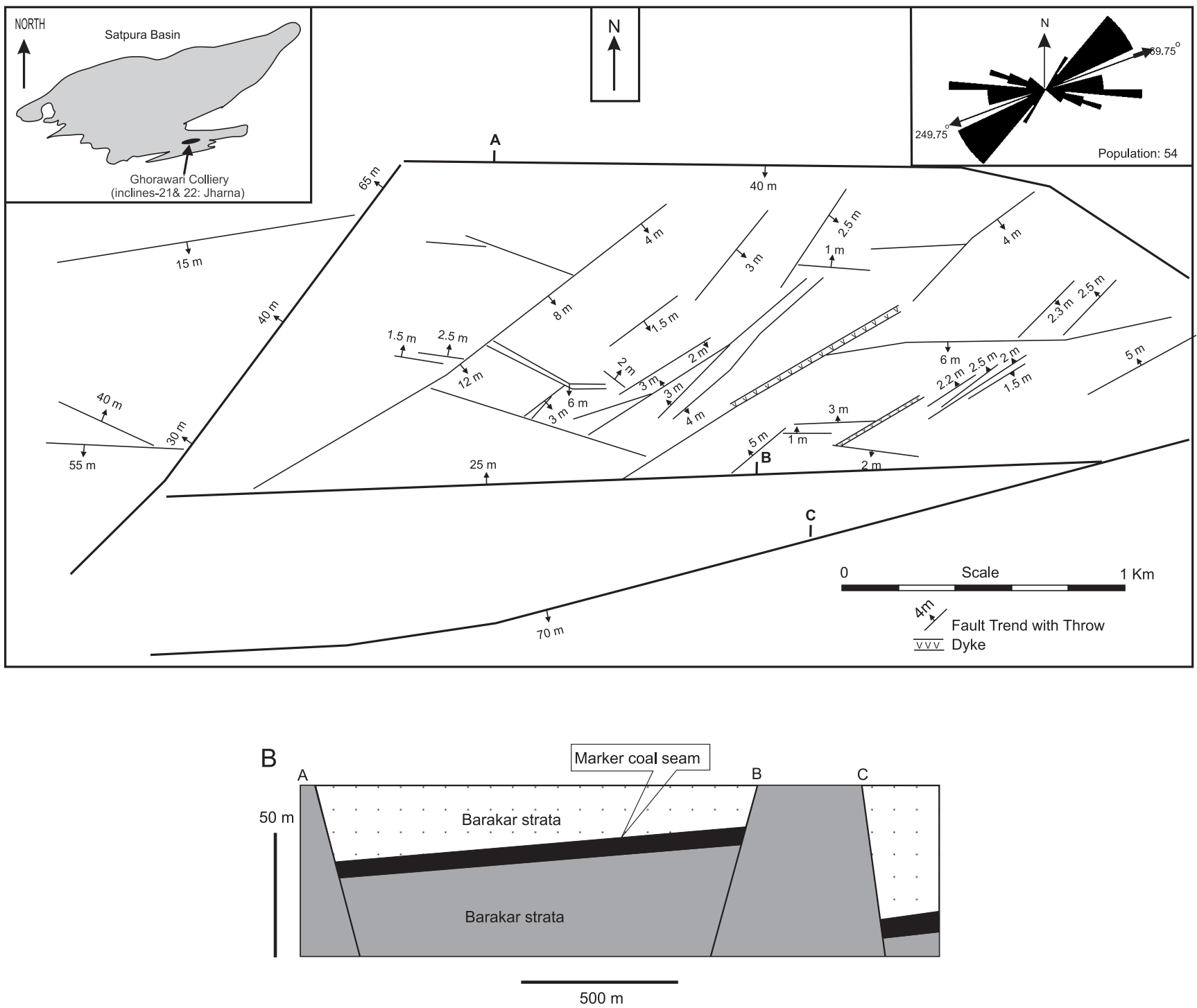

Figure 3. (A) Disposition of faults within the Barakar Formation of the Satpura basin as revealed from sub-surface mapping within a coal mine of the Pench-Kanhan valley, M.P. Note two sets of faults at angles with each other. Rose diagram depicts the orientation of the faults. Data source: Western Coalfields Limited. (B) Structural profile through the Barakar Formation constructed on the basis of data shown in A. Faults are marked by A, B, C which are also shown in the map in (A). Note graben-like configuration, asymmetric nature of the basin-fill and thickening of the hangingwall sediment fill (white, stippled) towards the fault A indicating synsedimentary nature of the faults.

are reflective of pull-apart basins developing in response to sinistral motion (Crowell 1974; Aydin and Nur 1985; Christie-Blick and Biddle 1985; Ingersoll and Busby 1995). It appears that this basin developed on a releasing jog along an ENEWNW trending intracontinental transcurrent zone with side steps due to sinistral strike-slip motion (figure 2B).

We performed analog model experiments with sandbox to understand

- its progressive evolution, and

- predict the architecture of the basin-fill, as outlined in the following sections.

\section{Experimental simulation}

\subsection{Experimental set-up}

A series of sandbox model experiments were performed to understand the tectono-sedimentary evolution of the Satpura basin. Experimentalists generally use two different set-ups for simulation of pull-apart basins. In one set-up, the sandpack rests over a basal plate containing side-stepping discontinuities with a stepover that divides the plate into two segments which are displaced laterally (figure 4I; cf. Dooley and McClay 1997). This method has one disadvantage that after a 
।

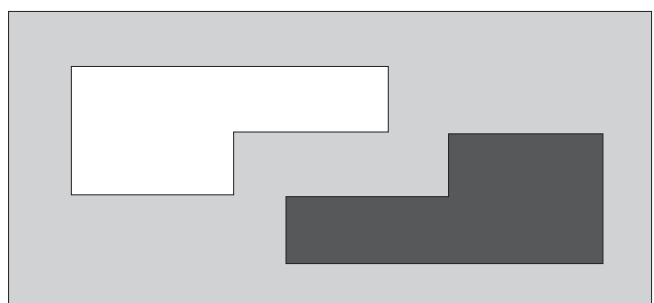

( A )
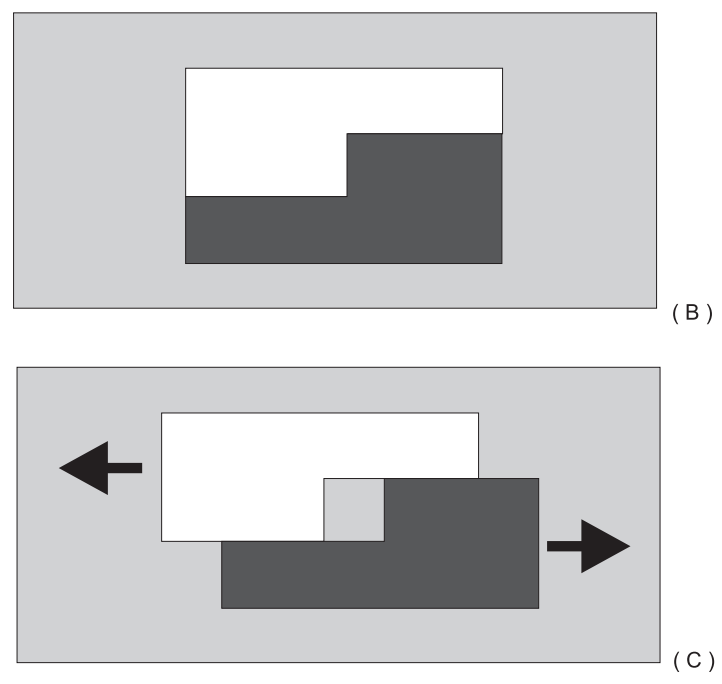

II

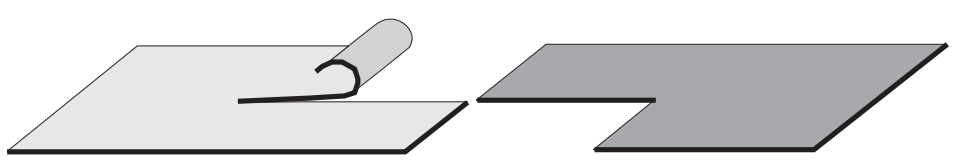

( A )
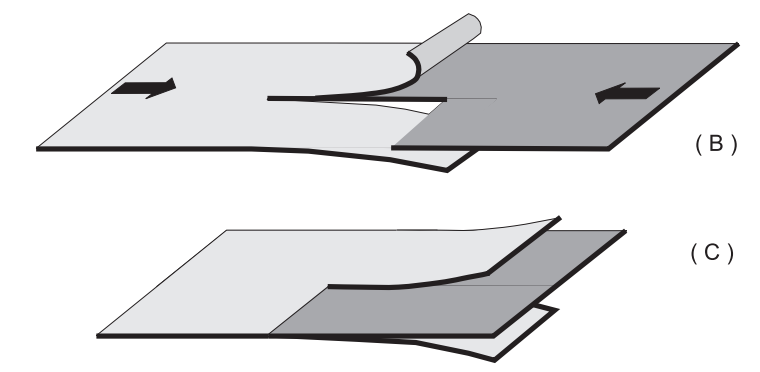

( C )

(D)

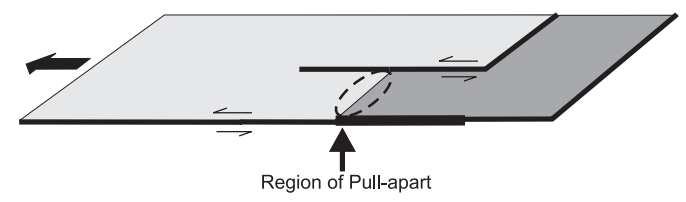

( E )

Figure 4. (I) Schematic representation of the progressive stages of arrangement of basal plates in the experimental set up for pull-apart basins (A, B). Note in (C) that following displacement of the basal plates the overlying sand-pack (not shown here) would be out of contact of the basal plates in the region of stepover. (II) Schematic representation of the progressive stages of arrangement of basal plates in the experimental set up devised in this study for pull-apart basins (A, B, C, D). Note in (E) that during displacement of the basal plates the overlying sand-pack (not shown here) would always remain in contact with the underlying plates in the region of stepover.

finite displacement the sandpack in the region of the stepover does not remain in contact with the basal plate, as a result the stresses due to movement of the plates are not transmitted to the sandpack (figure 4I). To overcome this limitation, an alternative experimental method is formulated, keeping a ductile layer between the sandpack and the basal plate (Basile and Brun 1999; Sims et al 1999). We have, however, designed a fairly simple, convenient but effective set-up without any ductile layer (figure 4II) in which the sandpack in the region of the stepover always remains in contact with the basal plate and suffers stress at all stages of displacement. In the experiments, the brittle crust was simulated by a layer of dry, quartz sand that undergoes failure according to CoulombNavier criterion (Horsefield 1977). Synkinematic sediments (dry sand) were added to the depressions at finite intervals to study progressive development of the basin and synsedimentary intrabasinal faults. The experimental results are reproducible and described below as observed in plan (figures 5 and 6$)$.

\subsection{Experimental results}

After a lateral basal plate-displacement of $0.5 \mathrm{~cm}$, a pair of parallel faults developed on the sandpack on either side of the underlying stepover defining the sidewall boundary faults of the experimental basin (figures $5 \mathrm{a}$ and $6 \mathrm{a}$ ). The faults make positive acute angles of $\sim 35^{\circ}$ with the shear direction verging opposite to the shear sense (sinistral). The fault lines were confined between the sidestepping, transcurrent discontinuities of the basal plate and were spaced at a distance of $6 \mathrm{~cm}$ along the shear direction defining the boundaries of the infantile basin. The faults dip towards each other and the displacement along them were obliqueslip in nature. The strike-slip component of the fault movement was synthetic to the bulk shear sense. The net vertical fall was very small (a few 

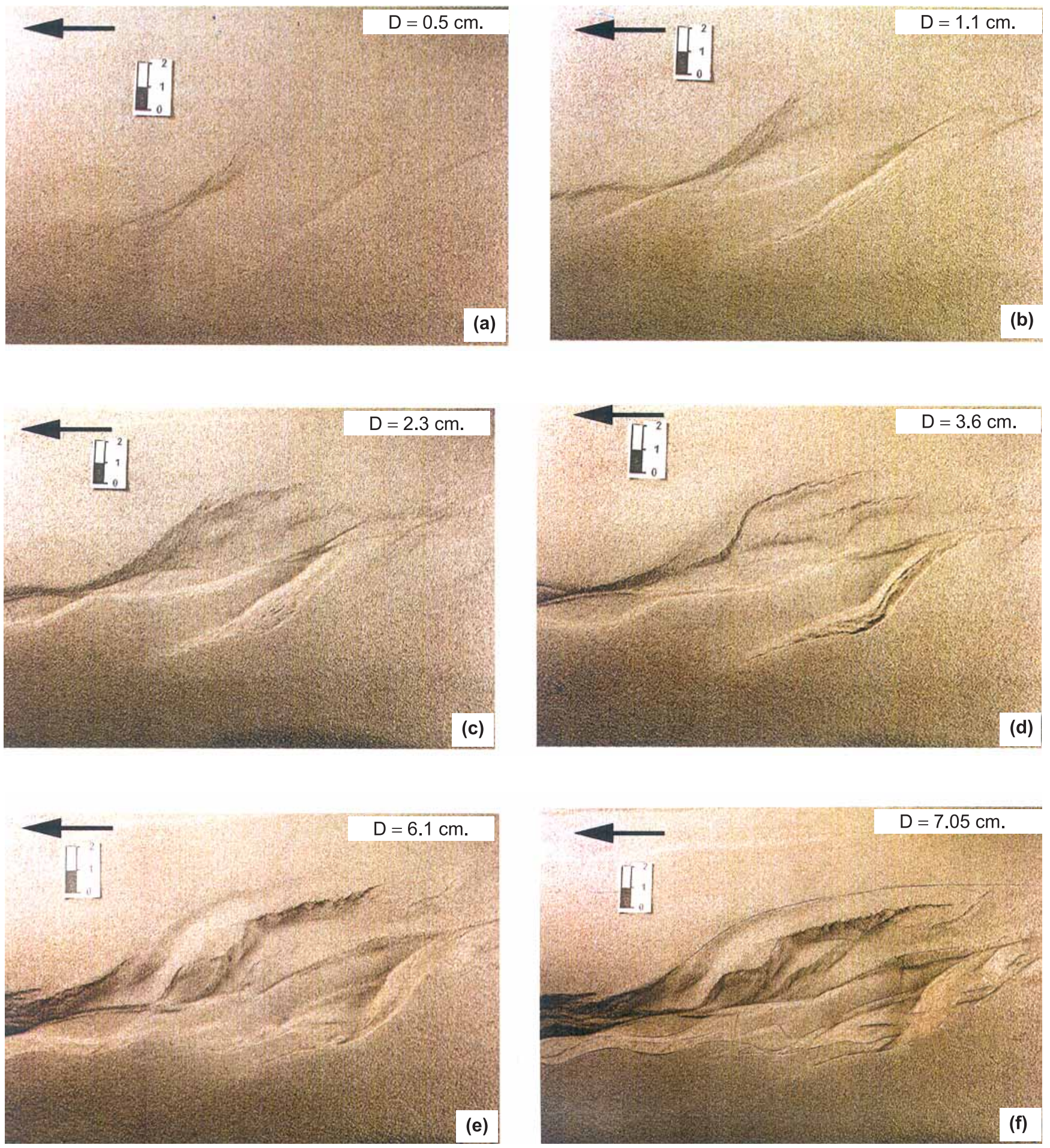

Figure 5. Plan views of successive stages of development of a pull-apart basin in sandbox model experiments above a left-stepping, transcurrent discontinuity due to sinistral strike-slip displacement of the basal plates. Displacement direction is marked by arrow and net displacement of the plate at each stage is shown at the top-right corners of the photographs. See text for details.

$\mathrm{mm})$ and was higher along the fault at the left margin. These faults resemble Riedel fracture system except that they are disposed at higher angles with the shear direction (cf. Dooley and McClay 1997).
After a lateral basal plate-displacement of $1.1 \mathrm{~cm}$, the sidewall faults lengthened and propagated progressively lowering their angle with the shear direction resulting in a finite sigmoidal geometry (figures $5 \mathrm{~b}$ and $6 \mathrm{~b}$ ). New faults also 


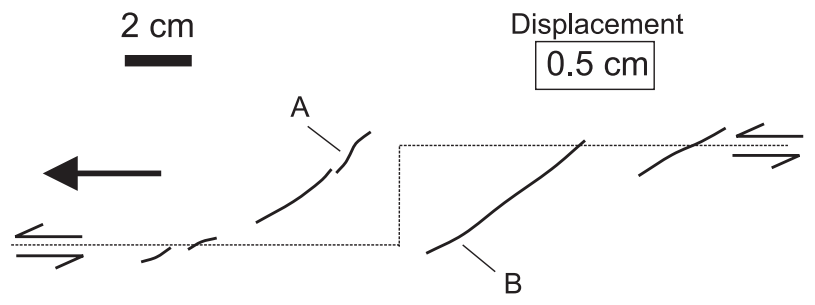

( A )

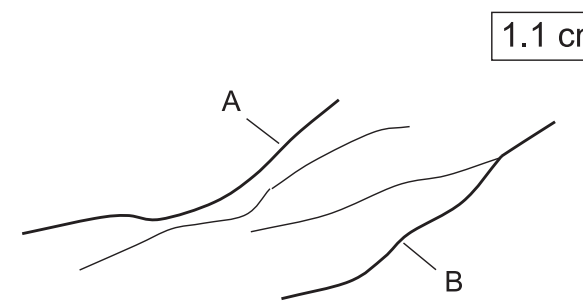

( B )

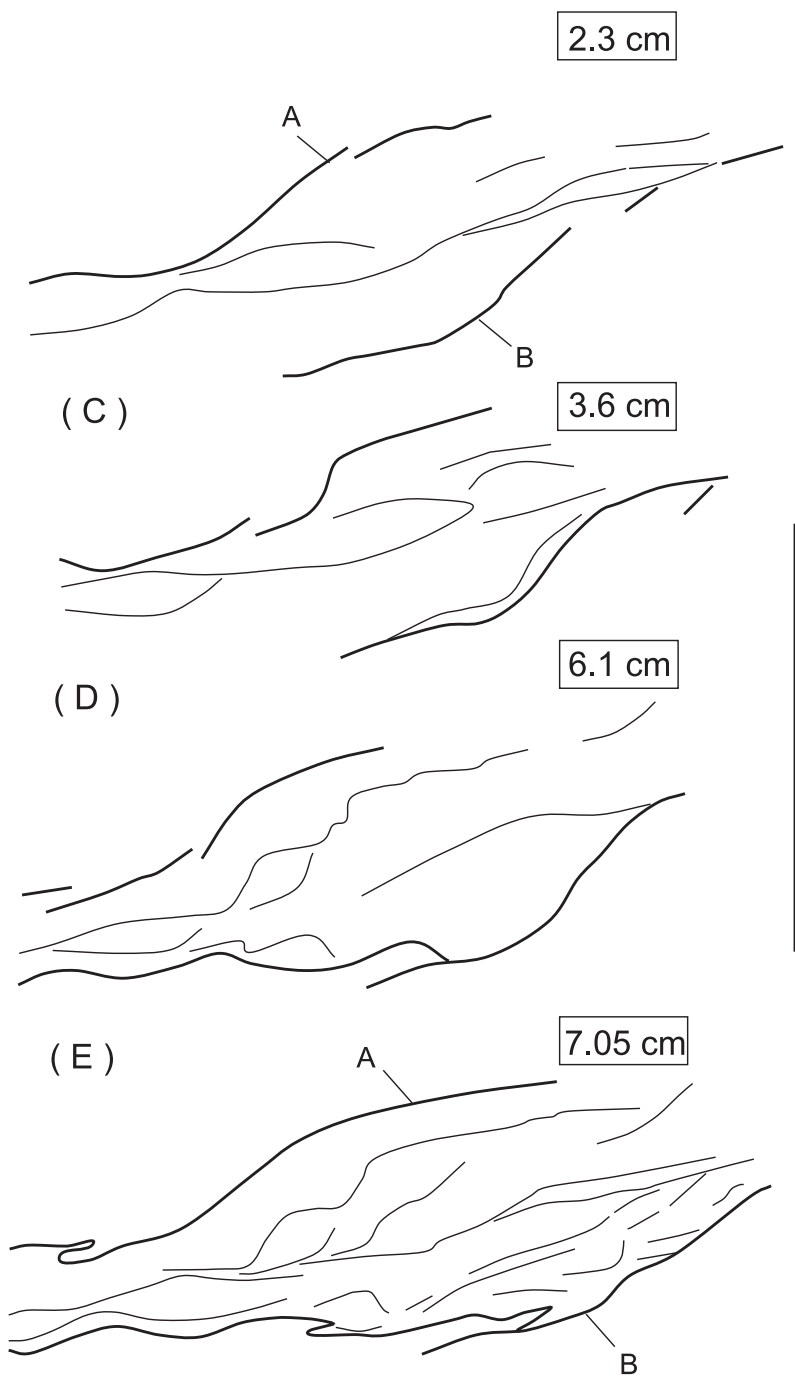

(F)

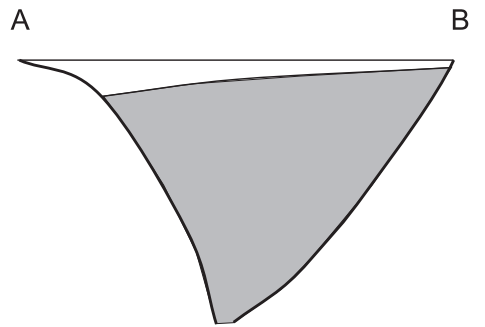

A

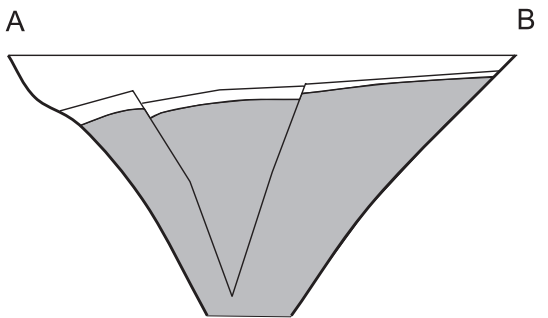

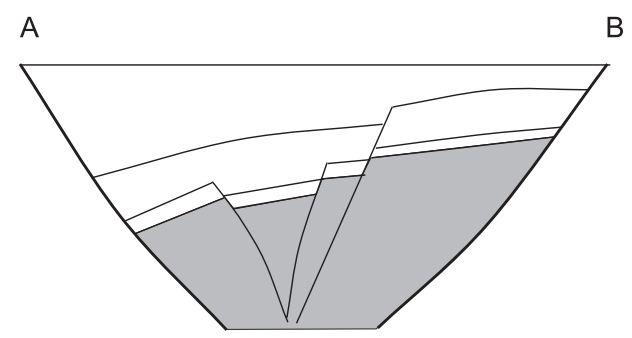

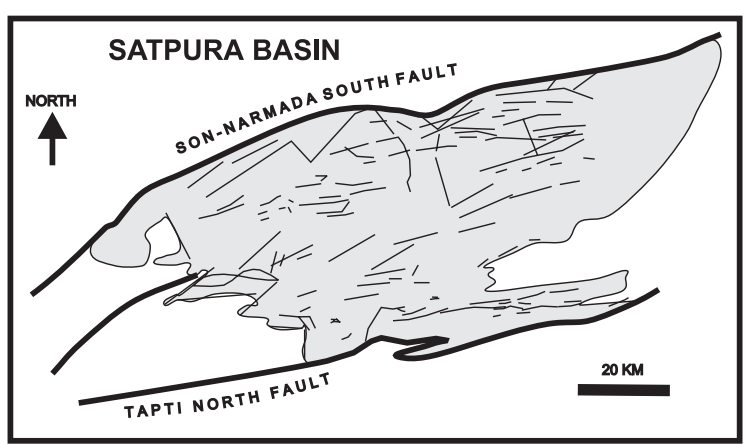

Figure 6. Line drawings of the plan views of the experimental model showing progressive developments of faults during formation of a pull-apart basin as shown in figure 5. Thick lines represent boundary faults and the thin lines are intrabasinal faults. Dotted line in (A) marks the basal discontinuity. Schematic profiles along A-B at each stage of experiment are shown at the right. Compare the fault pattern of the Satpura basin (in the inset) with that of the last stage of the experimental model. See text for details. 
developed making positive acute angles of $\sim 15^{\circ}$ with the shear direction. The spacing between the older sidewall boundary faults along the shear direction increased to $7.5 \mathrm{~cm}$. The new faults dip towards each other, were confined between and appeared to terminate against the relatively older faults. The nature of displacement along all the faults was oblique-slip with synthetic strike-slip components. The newer faults appear to represent synthetic Riedel shears. Net vertical fall along the faults increased and was larger along faults occurring leftward of the model.

After a displacement of $2.3 \mathrm{~cm}$, the older sidewall faults extended in length, attained a conspicuous sigmoidal geometry and defined a rhombohedral basin with a length of $10 \mathrm{~cm}$ along the shear direction (figures $5 \mathrm{c}$ and $6 \mathrm{c}$ ). The relatively newer faults extended and joined to form a through-going lineament along the diagonal of the rhomb that makes positive acute angle with the shear direction, linking the boundary faults. The faults dip towards left of the model. The vertical fall along the faults increased, the higher fall being along faults occurring towards left, but maximum subsidence appeared to have taken place slightly away from the leftward sidewall fault. At this stage of experiment, the depression was filled with dry quartz sand and leveled before further displacement.

Following sediment filling, the basal plate was further displaced, and when the finite displacement was about $3.6 \mathrm{~cm}$ several faults appeared in the newly added sediment pile. The previous boundary faults vertically penetrated into the new sediment pile and again defined a rhombohedral basin, but the sigmoidal boundary faults appeared to be kinked (figures $5 \mathrm{~d}$ and $6 \mathrm{~d}$ ). New faults developed within the basin mostly following the throughgoing fault observed at the previous stage and a few parallel to that trend. With further basal plate-displacements three principal changes were noticed:

- The length of the basin along the shear direction progressively increased and attained a length of $16 \mathrm{~cm}$ and width of $7.5 \mathrm{~cm}$ when the finite platedisplacement was $7.05 \mathrm{~cm}$.

- The kink of the boundary faults gradually flattened to become perfectly sigmoidal.

- Several sets of intrabasinal faults developed trending: (a) along and parallel to the antithetic diagonal of the rhombic basin, (b) antithetically at angles $15^{\circ}-20^{\circ}$ with the diagonal and (c) antithetically at angles $30^{\circ}-40^{\circ}$ with the shear direction (figures $5 \mathrm{e}, \mathrm{f}$, and $6 \mathrm{e}, \mathrm{f}$ ).

The faults along the antithetic diagonal of the rhombic basin defined a prominent lineament, which appeared to have divided the basin into two discrete grabens separated by an intrabasinal horst (figures $5 \mathrm{c}$ to $\mathrm{f}$ and $6 \mathrm{c}$ to $\mathrm{f}$ ). The experiments revealed that following the development of the through-going lineament, dominant subsidence took place in the graben occurring to the left of the lineament. Moreover, within the rapidly subsiding graben the subsidence rate varied spatially due to differential vertical falls along intra-graben faults. The faults at places branch out and rejoin resembling braids.

\section{Discussion}

Tallying the architecture of the experimental basin at the last stage with that of the Satpura basin (figures 5 and 6) reveals several corresponding features:

- The overall shape and the length-width ratio of the experimental basin resembles that of the Satpura basin,

- the intrabasinal fault pattern of the Satpura basin closely matches that of the experimental basin.

Combining the experimental observations with the structural and stratigraphic data of the Satpura basin (Raja Rao 1983) we have erected a structural profile of the basin (figure 7 ). The profile reveals that:

- The bulk of the Satpura succession was deposited in a mega half-graben bounded by basin margin faults represented by the SonNarmada south lineament and Tapti north fault. The half-graben geometry is also reflected in the profile of the Barakar Formation prepared from subsurface data (figure 3B).

- The subsidence rate varied across the basin resulting in an asymmetric basin-fill with the thickness increasing towards north.

- The basin-fill is transected by several synsedimentary gravity faults dipping northerly as well as southerly (figures 2 and 3A).

- The Pachmarhi Formation defines a monocline with its anticlinal bend underlain by a blind, subsurface gravity fault (figure 7) that follows the through-going cross-basin fault lineament linking the boundary faults and defining the axis of the basin.

\section{Tectonosedimentary evolution}

The Satpura succession is characterised by three major unconformities between (1) Basement and 


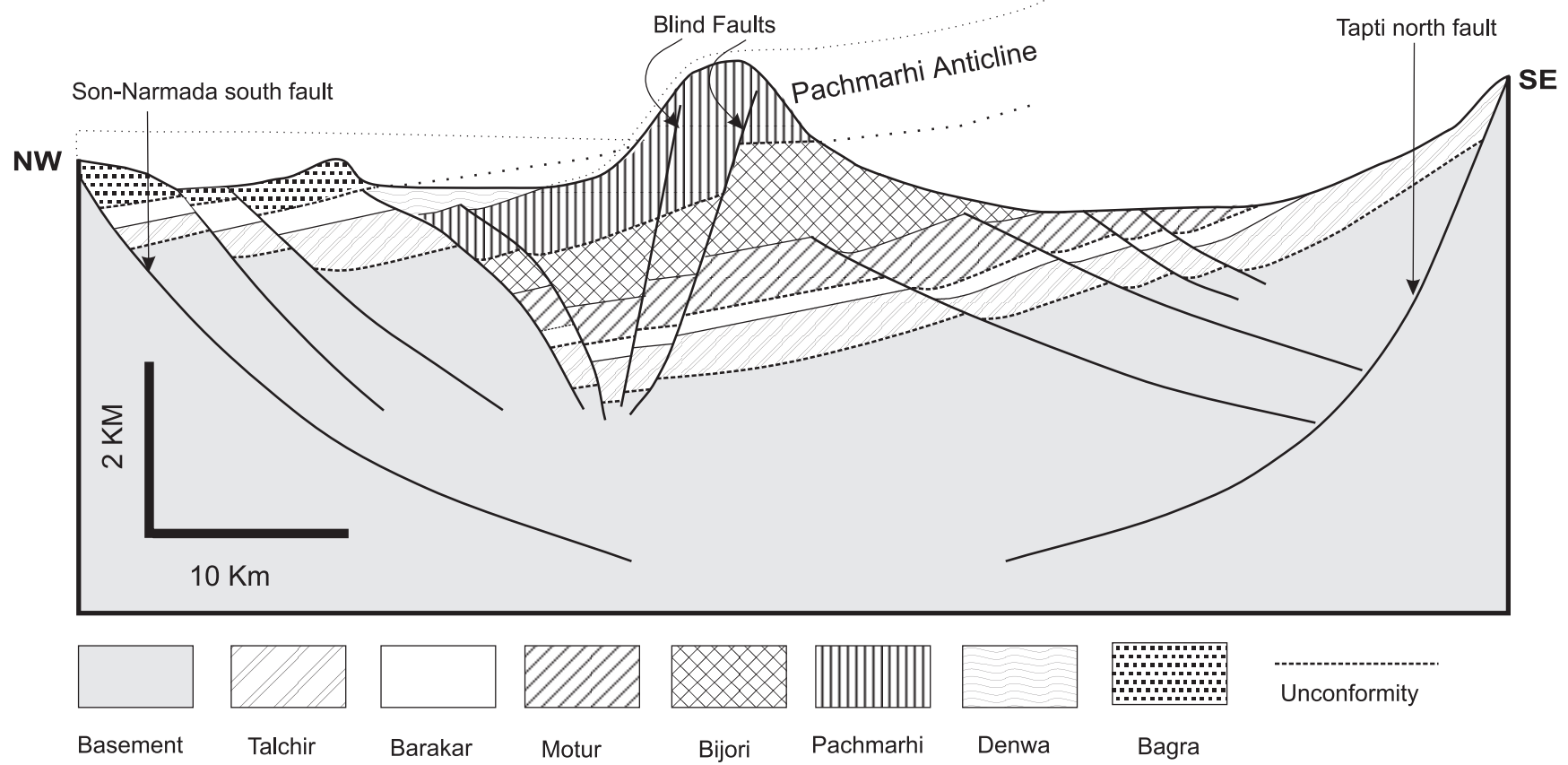

Figure 7. Cross-sectional profile of the Satpura basin as inferred from the experimental and field data (modified from Chakraborty et al 2003a). See text for details. Note half-graben configuration. Boundary faults are shown by heavy lines.

Barakar, (2) Bijori and Pachmarhi, and (3) Denwa and Bagra (Crookshank 1936; Casshyap et al 1993; Casshyap and Khan 2000; Chakraborty and Sarkar, this volume). The Barakar-Motur contact is sharp and the transition apparently represents a climatic shift towards aridity (Ray and Chakraborty 2002). Moreover, in the western part, the sandy Motur strata of braided fluvial origin sharply overlie the coal-bearing deltaic succession of the Barakar Formation (Chakraborty et al 2003b; Ghosh et al 2004). A sharp change from warm-humid deltaic to arid, fluvial condition suggests that the upper boundary of the Barakar Formation may also be an unconformity. These unconformities divide the Satpura succession into four distinct packages: (a) TalchirBarakar, (b) Motur-Bijori, (c) Pachmarhi-Denwa and (d) Bagra-Jabalpur. It is thus inferred that accumulation of the Satpura succession took place at least under four different fault-controlled subsidence regimes with intervening tectonically static periods as schematically shown in figure 8 . The termination of each faulting regime was followed by the development of unconformities.

Barring the Talchir Formation that comprises glacio-marine deposits, the rest of the Satpura Gondwana succession largely represents a variety of fluvial depositional systems with some records of fluvio-deltaic regime (table 1). Paleocurrent data from the fluvial and glacial outwash strata (figure 9) reveal the following:
- Both transverse and axial sediment dispersal systems prevailed in the Satpura basin.

- Three distinct patterns of fluvial sediment transport can be recognized:

(a) Dominance of southerly-fed transverse systems manifested in the Talchir, Barakar, Motur and sandy Pachmarhi strata,

(b) comparable dominance of southerly-fed transverse systems and easterly-fed axial systems with relatively feeble southerly dispersal as represented in the Bijori, muddy Pachmarhi, Denwa and Bagra strata,

(c) dominantly easterly-fed axial systems with subordinate northerly-fed transverse systems as manifested in the Jabalpur strata.

It may be noted that transverse sediment transport prevailed till the accumulation of Motur strata, and axial sediment transport began to take place along with transverse transport since accumulation of the Bijori strata and continued thereafter. It is inferred that transverse sediment transport took place when active subsidence in the basin was controlled by faults oriented at high angles to the shear direction. Following nucleation of faults making low angle with the boundary faults and defining through-going lineament in the basin axial sediment transport set in.

The Bagra Formation of alluvial origin reveals a polymodal paleocurrent rose spanning the whole 


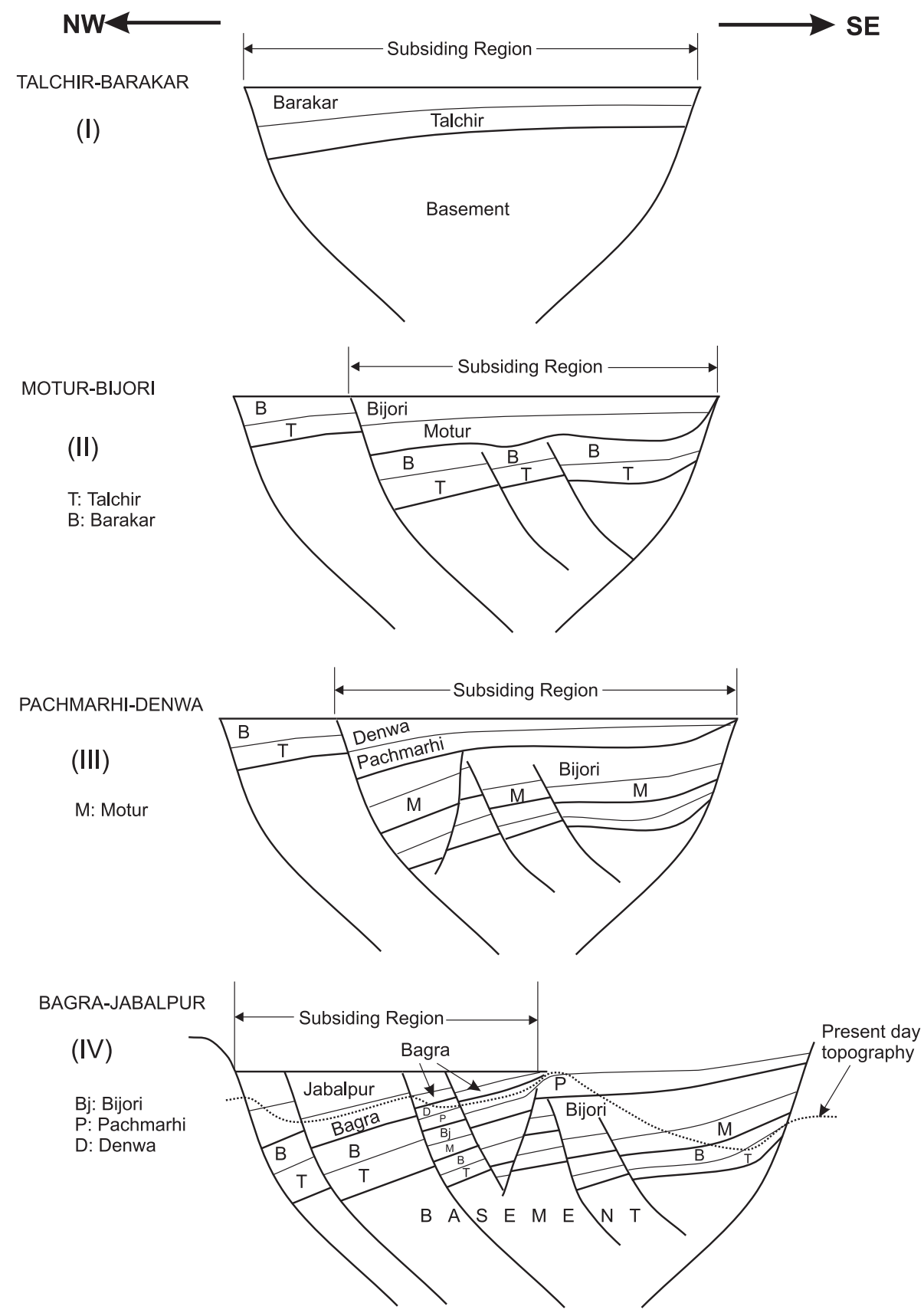

Figure 8. Four stages of development of the Satpura basin as inferred from the present study. See text for details. Unconformities are marked by thick lines.

compass indicating a contrasting basin morphology which received sediments from all sides implying the existence of transverse systems from both the margins as well as an axial system dominantly from the north-east (figure 9). The Bagra sediments are restricted along the northern margin of the halfgraben and are observed to unconformably overlie Denwa, Pachmarhi, Bijori and Talchir Formations at different places (Casshyap et al 1993; Maulik et al 2000). The infra-Bagra formations possibly suffered exposure and denudation before initiation of Bagra sedimentation. This perhaps implies that during Bagra period the active fault marking the southern limit of sedimentation was located within the basin far northward of the Tapti north fault defining the southern boundary of the Satpura basin. It has recently been documented from active, intracontinental transcurrent zones that development of pull-apart basin above the stepover of side-stepping discontinuities is followed by a tectonic regime when basin subsidence ceases to be controlled by the stepover between separate segments of principal displacement zone, but active subsidence is accommodated by oblique extension 


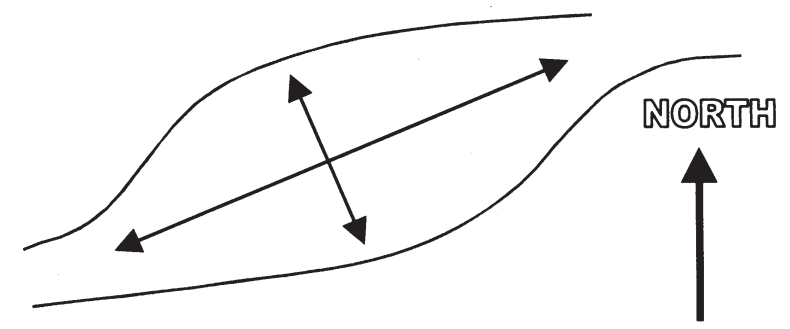

Outline of the Satpura Basin along with its axial and transverse axes

Talchir: Glacial Outwash

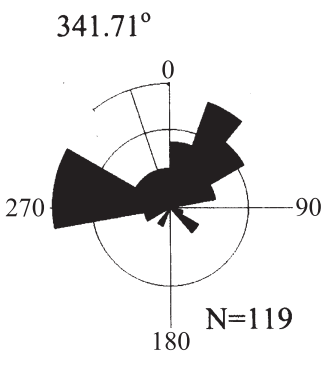

Upper Sandy Motur
Barakar: Fluvial

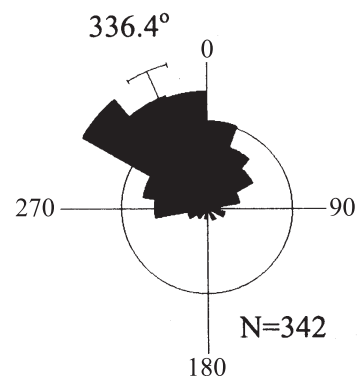

Bijori: Fluvial

\section{Lower Muddy Motu}

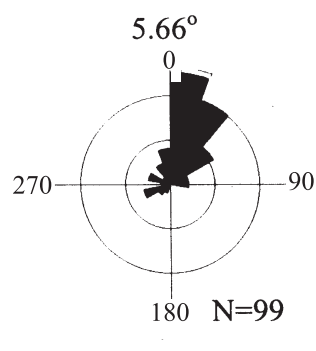

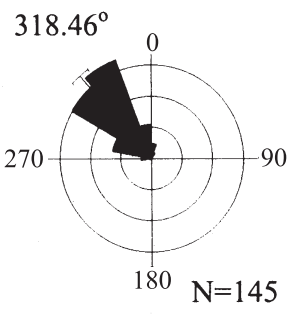

Sandy Pachmarhi

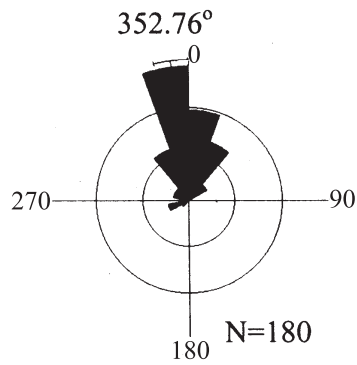

Muddy Pachmarhi

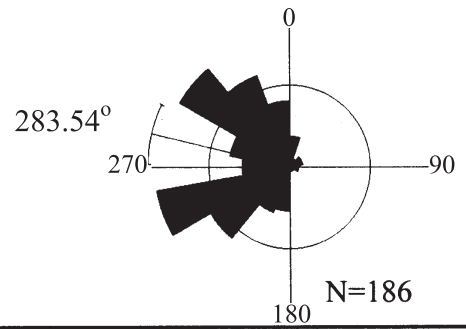

Lower Denwa
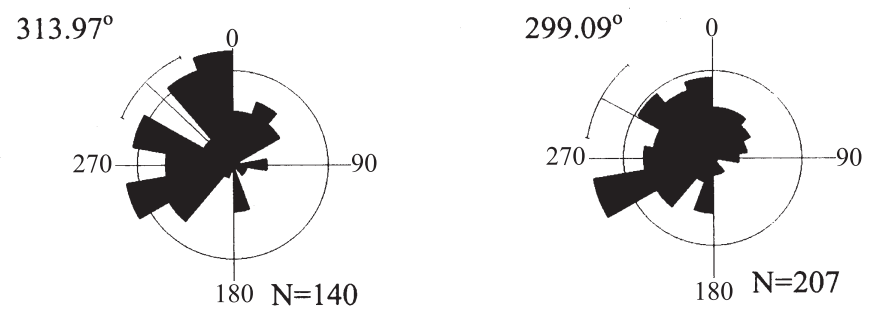
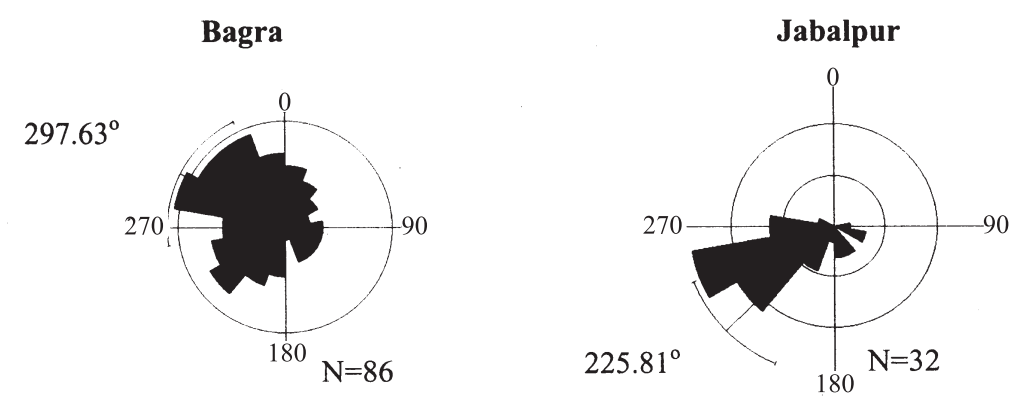

Figure 9. Paleocurrent rose diagrams of the glacial outwash and fluvial strata of the Satpura basin. Note progressive variation of the paleocurrent pattern with time attributable to different tectonic stages of basin evolution as shown in figure 8 (see text for details). 
on a through-going intrabasinal fault that developed at a stage during pull-apart regime (Barnes et al 2001). It appears that Bagra-Jabalpur strata represent such a tectonic stage of the Satpura basin when the southern half of the basin (with respect to the through-going fault lineament) was being relatively uplifted and the northern half was accumulating sediments (figure 8IV).

\section{Conclusions}

The principal outcome of the present study can be summarized as follows:

- The Satpura Gondwana basin of central India represents a pull-apart basin that developed above a releasing jog of a pre-existing transcurrent zone as a result of sinistral displacement. Rhombic shape of the basin and intrabasinal fault pattern support this contention.

- The subsidence of the Satpura basin was principally related to movement along two sets of faults, one making $\sim 35^{\circ}$ and the other $\sim 15^{\circ}$ positive angles with the direction of transcurrent movement.

- The overall basin architecture is that of a halfgraben which at a finite stage of tectonism was divided into two discrete segments by a throughgoing intrabasinal horst along the axis of the basin.

- The basin was filled by glacio-marine, glaciofluvial, fluvio-deltaic and fluvial depositional systems. Periods of maximum subsidence are indicated by fluvio-deltaic regimes that prevailed during Talchir, Barakar and Bijori sedimentation. Following Bijori sedimentation, accumulation in the Satpura basin took place under the alluvial regime indicating decrease in the rate of basin subsidence. Three distinct patterns of fluvial sediment transport can be recognized:

(a) Dominance of southerly-fed transverse systems,

(b) comparable dominance of southerly-fed transverse systems and easterly-fed axial systems,

(c) dominantly easterly-fed axial systems.

Axial sediment transport began following nucleation of faults making low angles to the basin margin and defining through-going lineament along the basin axis.

- At the terminal stage, sedimentation in the Satpura basin was confined to the northern half of the basin.

\section{Acknowledgements}

Financial assistance from the Department of Science and Technology, New Delhi is gratefully acknowledged. Prof. D Mukhopadhyay and Dr. W H Ryang are specially thanked for their constructive criticism. We are grateful to the Western Coalfields Limited, Pench-Kanhan valley, M.P. for providing the subsurface data. Indian Statistical Institute, Kolkata provided infrastructural facilities.

\section{References}

Aydin A A and Nur A 1985 The types and roles of stepovers in strike slip tectonics, In: Strike-slip deformation, basin formation, and sedimentation (eds) $\mathrm{K} \mathrm{T}$ Biddle and N Christie-Blick, SEPM Spec. Publ. 37 35-45.

Barnes P M, Sutherland R, Davy B and Delteil J 2001 Rapid creation and destruction of sedimentary basins on mature strike-slip faults: an example from the offshore Alpine Fault, New Zealand; J. Struct. Geol. 23 1727-1739.

Basile C and Brun J P 1999 Transtensional faulting patterns ranging from pull-apart basins to transform continental margins: an experimental investigation; J. Struct. Geol. $2123-37$.

Basu T N and Shrivastava B B P 1980 Structure and tectonics of Gondwana basins of peninsular India; Fifth International Gondwana Symposium, Wellington, New Zealand Pp. 177-182.

Biswas S K 1999 A review on the evolution of rift basins in India during Gondwana with special reference to western Indian basins and their hydrocarbon prospects. In: Proc. Indian National Sci. Acad. Special issue on Gondwana assembly: new issues and perspectives (eds) A Sahni and R S Loyal, Pp. 261-283.

Biswas S K 2003 Regional Tectonic framework of the Pranhita-Godavari basin, India; Journal of Asian Earth Sciences 21 543-551.

Casshyap S M and Qidwai H A 1974 Glacial sedimentation of late Palaeozoic Talchir diamictite, Pench valley coalfield, central India; Geol. Soc. Am. Bull. 85 749-760.

Casshyap S M and Khan A 2000 Tectono-sedimentary evolution of the Gondwanan Satpura basin of central India: evidence of pre-Trap doming, rifting and palaeoslope reversal; Journal of South African Earth Sciences 31 $59-66$.

Casshyap S M, Tewari R C and Khan A 1993 Alluvial fan origin of Bagra Formation (Mesozoic Gondwana) and tectonostratigraphic implications; J. Geol. Soc. India $\mathbf{5 6}$ 489-504.

Chakraborty C, Mandal N and Ghosh S 2003a Kinematics of the Gondwana basins of the peninsular India; Tectonophysics 377 299-324.

Chakraborty C, Ghosh S K and Chakraborty T 2003b Depositional Record of Tidal-Flat Sedimentation in the Permian Coal Measures of Central India: Barakar Formation, Mohpani Coalfield, Satpura Gondwana Basin; Gondwana Research 6 817-827.

Christie-Blick N and Biddle K T 1985 Deformation and basin formation along strike slip faults In: Strike-slip deformation, basin formation, and sedimentation (eds) K T Biddle and N Christie-Blick, SEPM Spec. Publ. 37 $1-35$.

Crawford A R 1978 Narmada-Son lineament of India traced into Madagascar; J. Geol. Soc. India 19 144-153. 
Crookshank H 1936 Geology of the two northern slopes of the Satpuras between the Morand and Sher rivers; $\mathrm{Mem}$. Geol. Surv. India 66 173-381.

Crowell J C 1974 Origin of late Cenozoic basins in southern California, In: Tectonics and Sedimentation (ed.) W R Dickinson, SEPM Spec. Publ. 22 190-204.

Das B and Patel N P 1984 Nature of the Narmada-Son lineament; J. Geol. Soc. India 25 267-276.

Dooley T and Mcclay K R 1997 Analog modelling of pullapart basins; American Association of Petroleum Geologists Bulletin 81 1804-1826.

Ghosh S K, Chakraborty C and Chakraborty T 2004 Combined tide and wave influence on sedimentation of Lower Gondwana coal measures of central India: Barakar Formation (Permian), Satpura Basin; J. Geol. Soc. London 161 117-131.

Harris L B and Beeson J 1993 Gondwanaland significance of lower Palaeozoic deformation in central India and SW Western Australia; J. Geol. Soc. London 150 811-814.

Hobday D K 1987 Gondwana coal basins of Australia and South Africa; tectonic setting, depositional systems and resources, In: Coal and coal-bearing strata: recent advances (ed.) A C Scott, Geol. Soc. London Spec. Publ. 32 219-233.

Horsefield W T 1977 An experimental approach to basement-controlled faulting; Geologie en Mijnbouw 56 363-370.

Ingersoll R V and Busby C J 1995 Tectonics of sedimentary basins. In: Tectonics of Sedimentary Basins (eds) C J Busby and R V Ingersoll, Oxford: Blackwell Scientific Publications, Pp. 1-52.

Kaila K L 1986 Tectonic framework of Narmada-Son Lineament; a continental rift system in central India from deep seismic soundings, Reflection seismology: a global perspective; American Geophysical Union, Geodynamics Series 13 133-150.

Maulik P K, Chakraborty C, Ghosh P and Rudra D 2000 Meso- and macro-scale architecture of a Triassic fluvial succession: Denwa Formation, Satpura Gondwana basin, Madhya Pradesh; J. Geol. Soc. India 56 489-504.
Mishra D C, Gupta S B, Rao M B S, Venkatarayudu and Laxman G 1987 Godavari basin - a geophysical study; J. Geol. Soc. India 30 469-476.

Mishra D C, Chandra Sekhar D V, Venkata Raju D Ch and Vijay Kumar V 1999 Crustal structure based on gravity-magnetic modelling constrained from seismic studies under Lambert Rift, Antarctica and Godavari and Mahanadi rifts, India and their interrelationship; Earth Planet. Sci. Lett. 172 287-300.

Naqvi S M, Rao D and Narain H 1974 The protocontinental growth of the Indian Shield and the antiquity of its rift valleys; Precambrian Research 1 345-398.

Narula P L, Acharyya S K and Banerjee J 2000 Seismotectonic atlas of India and its environs; Geological Survey of India 87 1-87.

Peters J and Singh S K 2001 Satpura basin - an example of pre-rift, syn-rift and post-rift Gondwana sedimentation in India; J. Geol. Soc. India 57 309-320.

Raja Rao C S 1982 Coalfields of India Vol-II, Coal resources of Tamil Nadu, Andhra Pradesh, Orissa and Maharashtra. Bulletin Geological Survey of India, Series A $4 \mathbf{5} 103$.

Raja Rao C S 1983 Coalfields of India Vol-III, Coal resources of Madhya Pradesh and Jammu \& Kashmir. Bulletin Geological Survey of India Series A 45204.

Raja Rao C S 1987 Coalfields of India Vol-IV Part I Coal resources of Bihar, Bulletin Geological Survey of India Series A 45.

Ray S and Chakraborty T 2002 Lower Gondwana fluvial succession of the Pench-Kanhan valley, India: stratigraphic architecture and depositional controls; Sedim. Geol. 151 243-271.

Robinson P L 1967 The Indian Gondwana Formations - A review; First Symposium on Gondwana Stratigraphy, Ar Del Plata, Argentina 201-268.

Sims D, Ferrill D A and Stamatakos J A 1999 Role of ductile decollement in the development of pull-apart basins: experimental and natural examples; J. Struct. Geol. 21 $533-554$

Veevers J J and Tewari R C 1995 Gondwana master basin of Peninsular India between Tethys and the interior of the Gondwanaland Province of Pangea; Memoir Geological Society of America 187 1-73. 